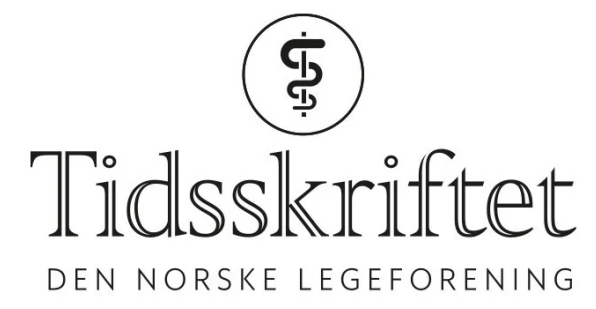

\title{
Profesjonalitet må læres
}

INTERVJU

EDVIN SCHEI

Email: edvin.schei@isf.uib.no

Universitetet i Oslo

Hva er medisinsk profesjonalitet? Og hvem er egentlig «den gode lege»? Vi har møtt fem studenter i «Profesjonalitetskomiteen» ved medisinstudiet i Bergen, til en samtale om læring, menneskelighet og strevet med å mestre den mektige legerollen.

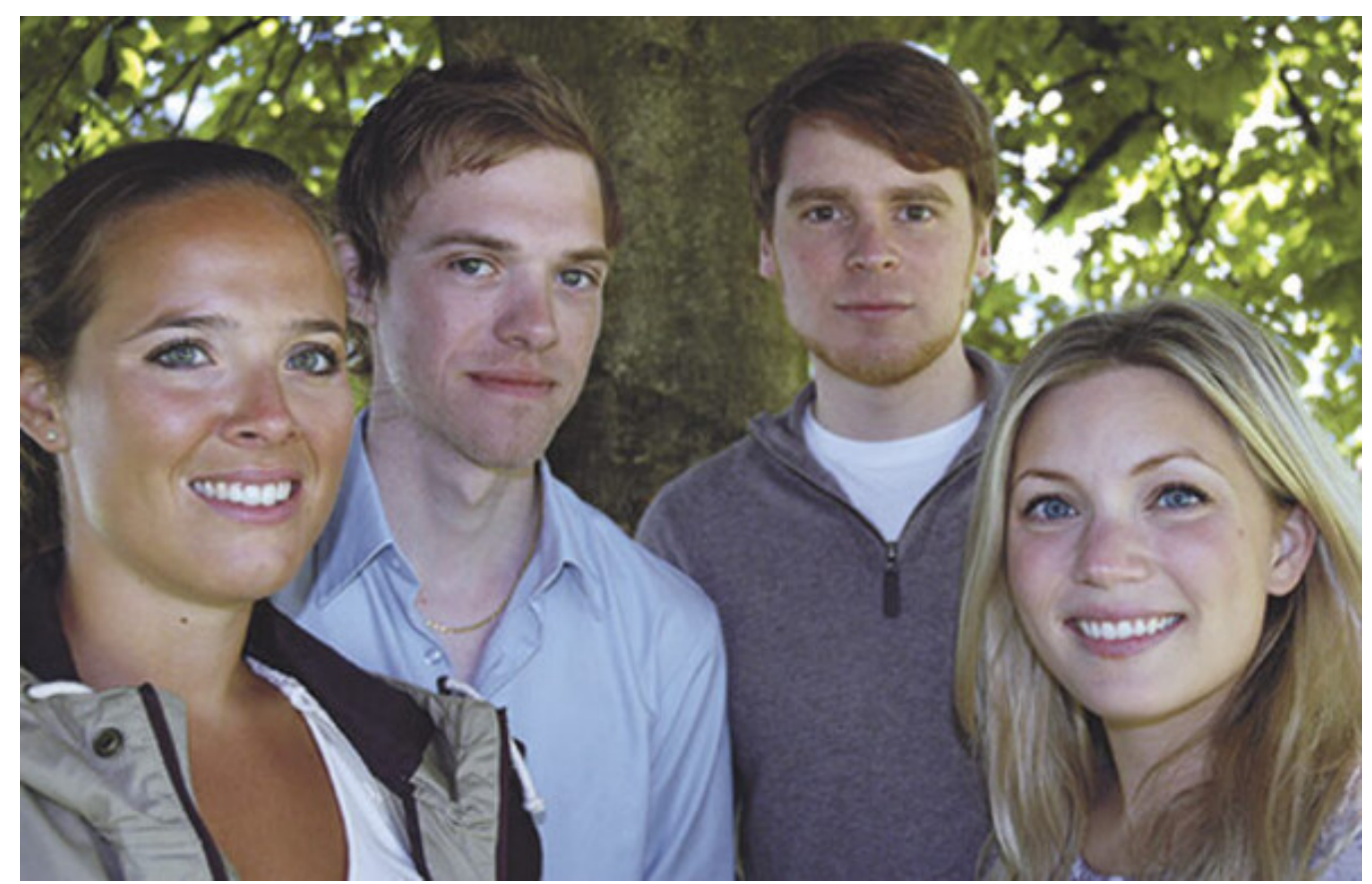

Fra venstre Ingrid Neteland, Eivind Valestrand, Karl Erik Müller og Else Fjøsne. Sofie Paus var ikke til stede da bildet ble tatt. Foto Edvin Schei 
"Besides medical school, there is probably no other four year experienceunless it be fouryears in a war-that can so change the cognitive content of one's mind and the nature of one's relationships with others.»«Francis

\section{Moore,»«Harvard Medical School»}

Portrettintervjuene i Tidsskriftet er samtaler om faget, mellom insidere. Intervjuerne er selv leger, man har hatter på hodet, interesser, hensikter. La meg bekjenne noen av mine før dette intervjuet med fem studenter slippes løs: Jeg er professor i allmennmedisin og iblant lærer for mine intervjuobjekter, og jeg leder komiteen de fem deltar i (Komité for læring av profesjonalitet, pasientsentrert kommunikasjon og mestring av legerollen ved medisinstudiet i Bergen). Gjennom aktiviteter i Filosofisk poliklinikk har jeg ivret for at legeutdanningen må endres, fordi studenter og unge leger gis for lite trygghet i å mestre og utnytte den potente legerollen. Som fastlege har jeg begrenset erfaring fra sykehusverdenen. Jeg kan mistenkes for å ri mine kjepphester i dette intervjuet, og mistanken vil være berettiget. Til den kritiske leser vil jeg likevel si: Legg merke til hva studentene sier. Kan de ha rett?

\section{Hva drømmer studenter om?}

Vi rusler i duskregn og svuppende myr, vestlandsfjellene ligger vårgrønne rundt oss, sauene napper vårens første friske gresstrå mellom krokete bjørkestammer. Fem unge mennesker i ivrig samtale. De velger å bruke tid på planer og utredninger for en ny medisinsk studieplan ved Universitetet i Bergen. De er en komitéleders «dream team»: ivrige, morsomme, erfarne, kritiske, utholdende og velformulerte. Hvorfor gjør de dette?

«Jeg velger å være med fordi jeg tror vi kan lage et supert studium i Bergen!» Det er Sofie Paus som snakker. Oslojenta har jobbet i en palestinsk flyktningleir. Hun har opplevd at også legestudiet kan være smertefullt.

- Motivasjon for å jobbe med studieplanen er lett å finne når man skjønner at vi er mange som strever med forestillingene om den ekstremt krevende legerollen. Hvordan er det meningen at jeg skal bruke meg selv? Snakket om altruisme kan virke kvelende. Ingen mennesker er bare edle, og den vanskelige samtalen skal aldri bli lett. Jeg synes det er mange undervisere som ubevisst formidler «hør på hva jeg sier og glem hva jeg gjør». Kanskje de også er redde for ikke å være gode nok? Når forbildene så sjelden deler sin undring med oss, kan det bli vanskelig for studentene å finne vei i det medisinske landskapet. Første steg er bevissthet. Hva er legerollen, hvordan er det plass til meg som menneske i den, når er det jeg gjør, godt nok?

Karl Erik Müller tar ordet:

- Det er bra at fakultetsledelsen vil gjøre studiet vårt bedre på det som har med pasientkontakt å gjøre. En del forskning tyder på at vi som legestudenter risikerer å bli mindre empatiske og mer selvsentrerte i den kliniske delen av studiet. Jeg tror det skyldes stress, bekymring og stor avstand til de erfarne legene. «Det skjulte pensum» handler om at man lærer av det forbilder sier og utstråler, man tilpasser seg det man tror alle andre gjør. Presset er stort. Varmen og idealismen man hadde i starten, blir fjernere når man strever for å klare seg på studiet. Man ser all lidelsen hos pasientene og kan ikke gjøre stort, må bare gå videre. Kynisme kan vokse frem, modningsprosesser gå i stå. Dette er det skrevet mye om (1). Min erfaring er dessverre at det kan stemme, men at vi ikke så lett merker det selv.

Jeg hater å høres så negativ ut, jeg er faktisk svært glad for at jeg studerer i Bergen. Her om dagen hadde vi for eksempel patologi. Og mens vi studerte snitt i mikroskopene kommenterte patologen: «Som leger kan dere glemme mye av patologien, det er greit. Men én ting kan dere ikke glemme - å være medmennesker!» 
Karl Erik er kritisk entusiastisk nyfiken. Han har gått på klosterskole i Tyskland, bodd et år på grisefarm hos en nibarnsfamilie på den kanadiske prærien og har en bachelor i samfunnsøkonomi fra London. Der startet han en norsk kunstfestival. Han har brasiliansk kone, leser filosofi og forsker på parasittsykdommen leishmaniasis.

- Jeg tenker at det er vår plikt å peke på ting som bør bli bedre, selv om vi har et bra studium allerede. Jeg drømmer om en virkelighet hvor vi kan bli oppriktig enige om at medisin er mer enn å tilegne seg drøvtygd kunnskap. Det handler om å være menneske, frisk eller syk. Vi glemmer det i en hektisk studiehverdag hvor vanskelig stoff skal læres og $i$ et stressende arbeidsliv hvor blodtrykk skal senkes og sår sys. Vi glemmer at mennesket ikke nødvendigvis er hjulpet selv om blodtrykket er blitt lavere og såret lappet. Vårt oppdrag som leger stopper ikke der, mener jeg. Det er uklart når vårt oppdrag egentlig stopper. For meg er det flott! Det finnes ingen fasit!

Han gestikulerer ivrig i rød regnjakke, vanndråpene flyr. Vi smiler og rusler videre mot tregrensen.

\section{Å føle seg som ugress}

Trønderjenta Else Fjøsne er energisk optimist og har ett år igjen av legeutdanningen, etter at hun valgte bort en karriere som musiker.

- Hvordan studenter behandles av leger, påvirker måten vi senere møter pasienter på.

Møtes vi som luft, lærer vi at det er slik ekte leger ser på folk. Å være god rollemodell er en stor oppgave. Mange av underviserne gjør den jobben fint, men det virker som om det er opp til den enkelte. Får våre veiledere veiledning?

Å være utplassert på et lite vestlandssykehus var veldig givende for meg. Men miljøene er så ulike. Nylig satt jeg klar på morgenmøterommet på en avdeling på Haukeland universitetssykehus. Legene kom inn, ingen enset meg, jeg var visst usynlig. Jeg introduserte meg likevel, fikk ingen respons. Ingen ga øyekontakt. Vi skulle ned på operasjonssalen for å teste ut noe nytt utstyr. «Gøy å få være med!», tenkte jeg. På operasjonssalen fikk jeg et mutt spørsmål om hvem jeg var, fra samme lege som jeg hadde hilst på for ti minutter siden. Man føler seg virkelig som ugress, og det er ikke hyggelig. Det planter dårlige holdninger. Man får ikke lyst til å gjøre sitt beste, faget kan bli uinteressant.

\section{Look to Sweden?}

Else tok eksamen i øre-nese-hals, øye, nevrologi og hud i Göteborg.

- På Sahlgrenska Universitetssjukhuset ble jeg overrasket. Vi studenter var verdt noe! Kursansvarlige leger hadde all praktisk undervisning selv. De tok bilde av oss første skoledag og lærte seg navnene. Vi fikk individuell oppfølging i undersøkelsesteknikk, de sjekket at vi gjorde det riktig. Medisinstudentene hadde egne pausearealer med gratis kaffe, kjeks og haugevis med mikrobølgeovner. Slikt spiller en rolle, det gir en følelse av at vi er viktige selv om vi «bare» er studenter.

- Da jeg kom hjem, skjønte jeg at Bergen har forbedringspotensial. Vi får sjelden personlig oppfølging når vi gjør noe klinisk. Jeg tror for eksempel aldri at min abdominalundersøkelse er blitt kvalitetssikret. Hvem vet om jeg kjenner den forstørrede leveren eller ikke? Når vi kommer ut i arbeidslivet, er jeg redd det lille vi lærte på kommunikasjonstrening, slipes vekk, og tilbake sitter de dårlige vanene som nedarves generasjon etter generasjon. Jeg har mange venner i turnustjeneste, de rapporterer at de bare raser gjennom blekka med medisiner, tidligere sykdommer, vannlating og avføring. Hvordan pasienten faktisk har det, annet som kan forklare sykdomsbildet, er underordnet. 
De har ikke tid, og gjør som de har sett andre gjøre. Vi forberedes så dårlig på det virkelige arbeidslivet. Tenk på sykepleierne, så tett de følges opp når de prøver seg i nye roller. Opplever ikke vi like mange vanskelig situasjoner i løpet av en dag på jobb?

\section{Vi må bli kommunikasjonseksperter}

Else fortsetter:

- Hvem er fremtidens lege? Ikke Google, selv om alle mulige medisinske oppslagsverk ligger på nettet. Jeg tror fremtidens leger må bli eksperter på kommunikasjon, det er ikke «prat».Vi må øve på å lytte, øve på å få tak i det pasienten vet. Mange diagnoser kunne blitt stilt tidligere om vi hadde lyttet bedre til hva pasienten forteller, hvem pasienten er, hva hun opplever. Leger kan gjøre mer for folk. Hippokrates sier det jo: Iblant helbrede, ofte lindre - alltid trøste.

Hvordan bygge tillit slik at folk tør snakke? Hvordan få informasjonen vi trenger fra pasienten, når de ikke forteller det spontant selv? Det tar ikke så mye lengre tid. Små triks for å få pasienten til å føle seg prioritert, som det å sette seg ned under visitten i stedet for å stå ruvende over sengen. Møte blikket. Jeg mener ikke at kommunikasjonsundervisning skal skvise ut sykdomsteori og praktiske ferdigheter, men vi trenger begge deler, og vi trenger øving, rettledning, tilbakemelding.

\section{Hvordan er det å være syk?}

Eivind Valestrand tar ordet. Den spinkle 24-åringen fra Bergen har ro i blikket, han vet hva legearbeid handler om:

- Jeg skulle ønske at legeutdanningen ga alle studenter innsikt i hva det betyr å være syk. Det er mye mer enn å ha en diagnose.

Eivind var et astmabarn, som liten ble han innlagt på Barneklinikken 10-14 ganger i året. «Det var i den perioden jeg fant ut at jeg ville bli lege. Tryggheten var nok viktig, å få hjelp med pusten.» Astmaen ble bedre, men gjennom fem år i ungdomstiden var Eivind livstruende syk. Som 17-åring lå han i en lenestol hele dagen, for svak til å klare mer enn langsom tusling over gulvet. Skolegang ble umulig, dager og netter fløt sammen i kvalme og apati. Næring fikk han gjennom en sonde fra nese til tynntarm. Vekten falt ned mot 45 kilo. Gastrisk parese (lammelse av magesekken) gjorde at alt han spiste, kom opp igjen. 18 år gammel fikk han fjernet magesekken. Langsomt begynte oppturen. Han kom inn på medisinstudiet. Eivind går på forskerlinjen. Hva han forsker på? Sammenhengene mellom tarm og hjerne. «Det er et samspill der som er utrolig fascinerende. Det vil jeg forstå mer av!»

- Hva betyr din egen sykehistorie for deg som medisinstudent?

- Det er fristende å legge den bort, tenke på hyggeligere ting. Men da vil jeg jo ikke ha noe igjen for alle de slitsomme årene. Så jeg har bestemt meg for å bruke det til å forstå hva slags leger vi trenger, og påvirke utdanningen så godt jeg kan. Jeg er takknemlig for høyteknologisk medisin, den reddet livet mitt. De legene jeg og familien min husker, er allikevel de som også forsto hvor sårbare vi var, at vi trengte oppriktighet, noen som møtte blikket, som sa unnskyld når ting skar seg. De dyktigste legene er både teknikere og helbredere, og de klarer å kombinere det fordi de setter seg inn i hvordan pasienten opplever situasjonen.

Vi er på toppen, rusler i tåke over store snøflekker, våte i fjellstøvlene.

\section{Studiet for dårlig selvtillit}


Ingrid Neteland er femteårsstudent, hun har allerede påvirket studiet ved å dra i gang et nytt kurs i kliniske undersøkelsesferdigheter og en stor trivselsundersøkelse blant studentene. Ingrid har laaange sosiale antenner, sier vennene. Hun har sju års erfaring fra demensavdeling: «Jeg er glad for alle stundene med dans, synging, baking og skravling med verdens fineste demente. En av damene ga meg det beste råd om valg av fremtidig kavaler: «Det er ikke alltid de med flosshatt som er de greieste». Det har jeg gjemt på i mange år, og jammen har hun rett!»

Ingrid har to ganger vakt oppsikt med "personlige opplevelser» i Tidsskriftet $(\underline{2}, 3)$. Under overskriften Medisinsk lettvekter - bare meg? skrev Ingrid: «Dette er studiet for dårlig selvtillit. Jeg synes det er påfallende at jeg snart har gått fire år på dette studiet og kan telle på én hånd hvor mange ganger jeg virkelig har følt at jeg er god på noe. Det kan være mange forklaringer på det. Jeg kan være dum. Eller jeg leser og øver for lite. Kanskje er det legene jeg treffer det er noe galt med, eller kanskje er jeg bortskjemt på skryt fra før? Har jeg hatt det for lett i livet?»

Ingrid fikk mange tilbakemeldinger fra medstudenter og leger som kjente seg igjen i teksten. «Noen fikk inntrykk av at jeg ønsket å bli leiet i hånden. Nei, vi må ta ansvar selv. Men hvordan skal jeg alene vite hvordan jeg skal mestre døende kreftpasienter, psykiatrisk utagering, døde kropper og livredde barn? Må jeg spørre min mor stadig vekk? Vi trenger rett og slett systemer som gir medisinstudenter profesjonell veiledning og konstruktiv tilbakemelding på det de presterer.»

\section{Medlidenhetsveiledning}

- To opplevelser viser hvor dårlig og godt det kan gå med tilfeldig oppfølging, fortsetter Ingrid. Første journalopptak: Min studievenninne og jeg hadde øvd på spørsmål og famlende undersøkelsesteknikker. Legen viste oss inn på et rom. Ingen forhåndsopplysninger. Damen i sengen hadde samme dag fått vite at hun hadde kreft og metastaser overalt. «Så mange spennende funn!» tenkte kanskje legen. Jeg får vondt i magen av å tenke på at vi brukte henne som et medisinsk kasus, stilte henne alle de helsprø spørsmålene som ikke var relevante for henne. For at vi skulle få en fin journal. Jeg skulle gjerne gått tilbake og satt meg ned, latt henne snakke om det som opptok henne: å få beskjed om uhelbredelig kreft. Ingen behandling. Du kommer til å dø. Aller mest er jeg sint på legen som ga oss den kvinnen som et glimrende kasus.

Jeg tror ikke vi blir bedre leger av å bli spesielt hardhudete. Jeg ser at erfarne folk har laget sine mestringsstrategier. Etter hvert finner vi våre metoder vi også (4). Men det vi gjør i selvforsvar, blir ikke særlig profesjonelt. Å beskytte seg ved å lage et panser mot andres fortvilelse er skummelt. Det er det motsatte av empati. Empati er å bli berørt. Uten empati er profesjonaliteten hul og kald.

Jeg fulgte palliativt team én uke. Etter dager med døende pasienter, sørgende pårørende og lite søvn sto jeg inne på et pasientrom og kjente: Nå klarer jeg ikke mer. Jeg gikk for meg selv, tårene trillet. Overlegen fant meg. Han bare satt der til jeg var ferdig å gråte. Han sa det var en normal reaksjon. Jeg trengte å høre det. Han sa jeg hadde opplevd tøffe saker som ingen skal gå uberørt gjennom. Og at jeg kommer til å lære å håndtere slikt. Til slutt sa han: «Du er så ung. Det er ikke tilfeldig at vi er mange gamle ringrever som meg i palliativt team.» Jeg fikk håp, skjønte at erfaring kan lære deg å møte andres lidelse uten å miste likevekten. Det er den fineste samtalen jeg har hatt på studiet, og den største opplevelsen av å bli sett. Selv om det ikke handlet om meg, men om veldig syke mennesker, og veldig triste barn som skulle miste en forelder, så var det en der som også så meg.

\section{Profesjonalitet}


De fem har gjennom profesjonalitetskomiteen bidratt til et nytt element på medisinstudiet i Bergen - et kurs i pasientkontakt hvor førsteårsstudentene vil møte 20 ulike pasienter, snakke med dem om sykdom og helse, og tenke gjennom hva medisinsk profesjonalitet innebærer. Professus betyr å erklære offentlig, den profesjonelle «erklærer» at hun kan hjelpe. Læresteder i utlandet bruker varierende definisjoner. Medisinstudiet i Bergen forankrer begrepet i pasientens perspektiv: Medisinsk profesjonalitet betegner de verdier, vceremåter og relasjoner som skaper tillit til leger hos enkeltpasienter og i samfunnet.

- Profesjonalitet er å kunne forene fagkunnskap, kliniske ferdigheter og moralsk dømmekraft. Har den nye profesjonalitetstenkningen noe med universitetenes generelle dannelsesdebatt å gjøre?

- Ja, svarer Else. Profesjonsfagene skal hjelpe mennesker. Oppgavene er alltid delvis uforutsigelige, man må vurdere der og da hva som er bra å si og gjøre. Faktakunnskap og regler må brukes med fornuft. Slikt arbeid kalles "praksis». Godt utbytte for pasientene avhenger av at hjelperne har teft, at de er nysgjerrige og åpne, at de klarer å finne ut hva som er viktig for pasienten, og kan skape løsninger.

- Og for å utvikle en slik praktisk fornuft må vi trenes til å tenke og handle som gode leger, ikke bare huske fakta, skyter Sofie inn. Dannelse handler om trening av hele personen. Preging i en fagkultur hvor man reflekterer over praksiserfaringene man får, målene man styrer etter, feilene man gjør og mestringen man opplever. Man skal lære ikke bare å gjøre ting riktig, men å gjøre riktig ting. Etikken må styre teknikken, det synes jeg er en fin formulering.

\section{Den ene lykkelige}

En time senere har vi kommet oss tilbake til hytta, det durer i ovnen, kaffen står på bordet. Vi snakker om trivsel. Eivind tar ordet: «En medstudent sa at hun aldri hadde møtt så mange perfekte mennesker før. Hvilket press lever studentene med hvis de opplever kollegene som perfekte? Alle har jo et behov for å passe inn, være som de andre. Jeg føler på det selv, jeg har ingen fysisk suveren kropp, er direkte svak og har aldri brydd meg om detfør jeg nå omgås en mengde veltrente folk. Plutselig føler jeg også et behov for å trene, tenke på utseendet. Å ville passe inn er naturlig. Å ville være perfekt er derimot en livsfjern lengsel som gjør at alle kan føle seg mislykket og selvopptatt. Hva slags leger blir vi da? En del studenter ville ha nytte av noen å snakke med om slike ting, om identitet, kropp og selvrespekt.

Jeg husker et ex. phil.-seminar der vi ble spurt om vi følte oss lykkelige. Jeg rakte opp hånden - som den eneste i rommet. De andre tenkte kanskje at jeg var litt overfladisk, mens jeg ble sittende og fundere på hvorfor jeg følte meg lykkelig, noe jeg helt klart gjorde på den tiden. Livet var godt, hvorfor følte de seg ikke lykkelige? Jeg innså at min egen lykke var knyttet til å være frisk. Jeg hadde kjent på avgrunnen, ikke å ha noe liv. Jeg tenker at det var en ganske brutal intervensjon for å kjenne lykke, det må finnes lettere måter. Det er et faglig poeng her. Vi må som hjelpere ha det bra med oss selv hvis vi skal klare å gi noe til dem som ikke har det bra.»

\section{Studenter kan påvirke}

- Hva trenger vi, og hvordan kan dere som studenter påvirke studiet?

- Vi trenger mentorgrupper som følger oss gjennom studiet, sier Sofie.

- Og tenk om mentor hadde så mye som 15 minutter per år til å snakke med bare meg, høre hvordan det går, om jeg klarer meg? skyter Karl Erik inn. 
- Jeg håper fakultetet ansetter flere som kan jobbe med pedagogikk, læringsformer og internundervisning for de ansatte, og tar i bruk eldre studenter som veiledere for yngre, sier Ingrid. Jeg har som studentrepresentant truffet leger og ledere som er opptatt av å høre min mening, jeg er glad for innflytelsen vi har hatt.

- Når jeg som student blir lyttet til og får lov å bidra med ideer, da blir jeg engasjert og legger gjerne ned utallige arbeidstimer. Jeg tror studentinvolvering er alfa og omega for å lykkes, sier Karl Erik. Else tar ordet:

- I denne komiteen har alle vært interessert i selve prosjektet, fokus har vært på målet, ikke på egen navle. Det gir meg tro på at vi får noe til.

\section{Den viktige huskelisten}

- Mange mener studiet er bra som det er, sier Ingrid. Noen tenker at profesjonalitet er folkeskikk man lærer i barndommen, noe iboende og ikke noe man skal undervises i. De burde ta en titt i speilet når de begynner på studiet, og titte igjen når de er ferdig. Det skjer noe på den veien, jeg merker det selv. Jeg har av og til mer enn nok med EKG-et eller blodgassen, og jeg glemmer å se at det er et helt menneske der. Det betyr ikke at jeg vil bli en dårlig lege. Det avslører bare at det viktigste i legeyrket, å se ting fra pasientens side selv om man må løse tekniske oppgaver, er noe av det vanskeligste å lære. Derfor må profesjonalitet hele tiden undervises i, snakkes om og huskes på.

Det er sen ettermiddag. Vi rydder, låser hytta og drar ned fra fjellet.

- Eivind Valestrand, 24 år, medlem av medisinsk fagutvalg og fakultetets arbeidsgruppe for nye lærings- og evalueringsformer, tillitsvalgt på forskerlinjen.

- Else Fjøsne, 28 år, medlem av fakultetets arbeidsgruppe for ny studiestruktur, redaksjonsmedlem i studentmagasinet Status Presens.

- Karl Erik Müller, зo år, forskerlinjestudent, medlem av Filosofisk poliklinikk.

- Ingrid Neteland, 26 år, medlem av medisinsk fagutvalg, mental helse-gruppen og fakultetets arbeidsgruppe for nye lærings- og evalueringsformer.

- Sofie Paus, 25 år, leder av MedFred, studentavdelingen av Norske leger mot atomvåpen.

\section{LITTERATUR}

1. Cruess RL, Cruess SR, Steinert Y. red. Teaching medical professionalism. New York, NY: Cambridge University Press, 2009.

2. Neteland I. Medisinsk lettvekter - bare meg? Tidsskr Nor Legeforen 2012; 132: 696-7.

3. Neteland I. Hvor er du? Tidsskr Nor Legeforen 2013; 133: 1340-1. [PubMed]

4. Johansson KA, Ohldieck C, Aase M et al. Skjebnezapping-medisinsk grunnopplæring, legestudenters dannelse og den etiske fordring. Tidsskr Nor Legeforen 2001; 121: 1618-21. [PubMed]

Publisert: 20. august 2013. Tidsskr Nor Legeforen. DOI: 10.4045/tidsskr.13.0818

(C) Tidsskrift for Den norske legeforening 2023. Lastet ned fra tidsskriftet.no 26. april 2023. 